\title{
Inhibition of the Insulin-Like Growth Factor-1 Receptor Enhances Effects of Simvastatin on Prostate Cancer Cells in Co-Culture with Bone
}

\author{
Annika Nordstrand • Marie Lundholm • \\ Andreas Larsson • Ulf H. Lerner • Anders Widmark • \\ Pernilla Wikström
}

Received: 8 October 2012 / Accepted: 8 January 2013 / Published online: 22 January 2013

(C) The Author(s) 2013. This article is published with open access at Springerlink.com

\begin{abstract}
Prostate cancer (PC) bone metastases show weak responses to conventional therapies. Bone matrix is rich in growth factors, with insulin-like growth factor-1 (IGF-1) being one of the most abundant. IGF-1 acts as a survival factor for tumor cells and we speculate that bone-derived IGF-1 counteracts effects of therapies aimed to target bone metastases and, consequently, that therapeutic effects could be enhanced if given in combination with IGF-1 receptor (IGF-1R) inhibitors. Simvastatin inhibits the mevalonate pathway and has been found to induce apoptosis of PC cells. The aims of this study were to confirm stimulating effects of bone-derived IGF-1 on PC cells and to test if IGF-1R inhibition enhances growth inhibitory effects of simvastatin on PC cells in a bone microenvironment. The PC-3 and 22Rv1 tumor cell lines
\end{abstract}

Electronic supplementary material The online version of this article (doi:10.1007/s12307-013-0129-z) contains supplementary material, which is available to authorized users.

A. Nordstrand · A. Widmark

Department of Radiation Sciences, Oncology, Umeå University, 90185 Umeå, Sweden

M. Lundholm • P. Wikström $(\bowtie)$

Department of Medical Biosciences, Pathology, Umeå University, 90185 Umeå, Sweden

e-mail: pernilla.wikstrom@medbio.umu.se

A. Larsson

Department of Chemistry, Umeå University, Umeå, Sweden

U. H. Lerner

Department of Molecular Periodontology, Umeå University,

Umeå, Sweden

U. H. Lerner

Centre for Bone and Arthritis Research at Institute of Medicine, Sahlgrenska Academy at University of Gothenburg,

Gothenburg, Sweden showed significantly induced cell growth when co-cultured with neonatal mouse calvarial bones. The tumor cell IGF-1R was activated by calvariae-conditioned media and neutralization of bone-derived IGF-1 abolished the calvarium-induced PC-3 cell growth. Treatment of PC-3 and 22Rv1 cells with simvastatin, or the IGF-1R inhibitor NVP-AEW541, reduced tumor cell numbers and viability, and induced apoptosis. Combined simvastatin and NVP-AEW541 treatment resulted in enhanced growth inhibitory effects compared to either drug given alone. Effects of simvastatin involved down-regulation of IGF-1R in PC-3 and of constitutively active androgen receptor variants in $22 \mathrm{Rv} 1$ cells. In conclusion, we suggest that IGF-1 inhibition may be a way to strengthen effects of apoptosis-inducing therapies on PC bone metastases; a possibility that needs to be further tested in pre-clinical models.

Keywords Prostate cancer · Bone metastases · IGF-1R . Simvastatin · Cholesterol

\section{Introduction}

The skeleton is the most frequent site for metastases of prostate cancer (PC) [1], and as there are no curable treatments for metastatic disease there is a great need for new therapeutic strategies targeting bone metastases. The mineralized bone matrix contains a wide range of growth factors, where insulin-like growth factor-1 (IGF-1) is one of the most abundant [2]. When metastases are formed in the bone they activate osteoclastic bone resorption and growth factors such as IGF-1 and transforming growth factor- $\beta$ (TGF- $\beta$ ) are released into the bone marrow cavity where they influence the metastatic tumor cells. Although PC bone metastases generally form sclerotic metastases, the bone metastasis process also includes 
a lytic component [3]. Accordingly, we previously showed that PC cells were able to induce lytic activity of bone, and the release of bone-derived IGF-1, when grown in co-culture with calvariae [4]. There is increasing evidence that the IGF family is involved in the development and progression of many cancer types, including PC. Several studies have shown that a high concentration of circulating IGF-1 is associated with an increased risk of PC [5, 6], and overexpression of the IGF-1 receptor (IGF-1R) has been observed in prostate tumors and metastases [7-11]. The IGF-1R is a receptor tyrosine kinase (RTK) that upon activation by IGF-1 shows mitogenic and anti-apoptotic effects $[12,13]$, and is believed to be important for oncogenic transformation (reviewed in [14]). Inhibition of the IGF-1R has been shown to impair tumor cell growth in vitro and in vivo (reviewed in [15])

Since IGF-1 is a strong survival factor for tumor cells we speculate that effects of apoptosis-inducing cancer therapies, such as castration, given with the intention to treat $\mathrm{PC}$ bone metastases, are possibly attenuated by high IGF-1 levels in the bone environment. Furthermore, we believe that effects of those therapies could be enhanced if given in combination with IGF-R1 inhibition. A number of strategies to target IGF-1R signaling have been tested in clinical trials, including neutralizing IGF-1 antibodies, anti-sense and RNA interference strategies to the IGF-1R, and inhibition of IGF$1 \mathrm{R}$ signaling by antibodies or tyrosine kinase inhibitors (reviewed in [16]).

We have previously found that PC bone metastases contain high levels of cholesterol [17]. Furthermore, it has been shown that cholesterol targeting drugs; statins, are able to induce apoptosis of PC cells in vitro $[18,19]$. Statins are 3-hydroxy3-methylglutaryl-coenzyme A (HMG-CoA) reductase inhibitors targeting the rate-limiting step of cholesterol synthesis, and have been prescribed during the last decades for prevention of cardiovascular diseases. Large epidemiological studies have indicated that statins may also reduce the risk of developing PC, particularly in its aggressive forms, although results are not completely conclusive (reviewed in [20]). The aim of this study was to confirm stimulating effects of bone-derived IGF-1 on PC cells in an in vitro model for tumor cell and bone cell interactions, and furthermore to test if IGF-1R inhibition could enhance growth inhibitory effects of simvastatin on PC cells in this model system.

\section{Results}

Prostate Cancer Cells are Stimulated by Bone Derived IGF-1

To determine if prostate tumor cells show increased growth in a bone microenvironment, PC-3 and 22Rv1 cell lines were cocultured with mice calvariae in a two-chamber in vitro model as previously described in Nordstrand et al. [4]. After $72 \mathrm{~h}$ in co-culture, the number of PC-3 and 22Rv1 cells was increased 1.2-fold compared to cell numbers observed when the tumor cell lines were cultured without calvariae $\left(P=1.2 \times 10^{-5}\right.$ and $3.6 \times 10^{-5}$, respectively, Fig. 1), suggesting that bone-derived factors were favoring the growth of the tumor cells.

To identify calvariae-derived factors with possible growthpromoting effects on $\mathrm{PC}$ cells, the phosphorylation status of 42 RTKs in PC-3 and 22Rv1 cells were analyzed before and after stimulation with calvariae-conditioned media. The IGF$1 \mathrm{R}$ was one of the most clearly activated RTKs by calvariaeconditioned media, showing 5.6 and 2.9 times increased phosphorylation levels in PC-3 and 22Rv2 cells, respectively (Supplemental Fig. S1). Moreover, mean levels of mouse IGF-1 (calvarial-derived IGF-1) were increased 1.6 and 1.4 times in the media when calvariae were co-cultured with PC-3 and $22 \mathrm{Rv} 1$ cells for $72 \mathrm{~h}$, respectively, as compared to the mean control IGF-1 level $(1,800 \mathrm{pg} / \mathrm{ml})$ reached when calvariae were cultured without tumor cells $\left(P=2.7 \times 10^{-5}\right.$ and $6.1 \times$ $10^{-3}$, Fig. 2). No IGF-1 was detected in conditioned media from tumor cells cultured without calvariae (data not shown), indicating the mouse specificity of the ELISA used. Very low levels $(<94 \mathrm{pg} / \mathrm{ml})$ of human IGF-1 were detected in the conditioned media from PC-3 and 22Rv1 tumor cells cultured alone, and there was no induction of either IGF-1 mRNA in the tumor cells or of human IGF-1 protein in the media after $72 \mathrm{~h}$ in co-culture with calvariae (data not shown), which is in line with previous results shown for PC-3 and LNCaP cells [4]. From these results we hypothesized that PC cells in coculture with mice calvariae were able to induce release of bone-derived IGF-1 into the surrounding, resulting in subsequent activation of the IGF-1R in tumor cells and stimulation of tumor cell growth.

To examine if the growth stimulatory effects on tumor cells observed in co-culture with calvariae could be explained by the release of IGF-1 from bone, we added excess of a neutralizing antibody against mouse IGF-1 to the media. Results showed that when mouse IGF-1 was neutralized, the bonederived effect on PC-3 cell numbers was completely abolished, while in $22 \mathrm{Rv} 1$ it was not significantly reduced $(P=$ 0.60 ) indicating that calvariae-derived factors other than IGF1 significantly affected 22Rv1 growth (Fig. 1b). Notably, the neutralizing antibody for mouse IGF-1 had no direct effect on tumor cells grown in absence of mouse calvariae (Fig. 1).

Simvastatin and NVP-AEW541 Reduce Prostate Cancer Cell Viability and Induce Apoptosis, and in Combination They Give Enhanced Effects

To further investigate the role of IGF-R1 signaling in this system, the small molecule IGF-1R kinase inhibitor NVPAEW541 [21, 22] was used to inhibit PC-3 and 22Rv1 cells. The tumor cell viability after $72 \mathrm{~h}$ of NVP-AEW541 treatment 


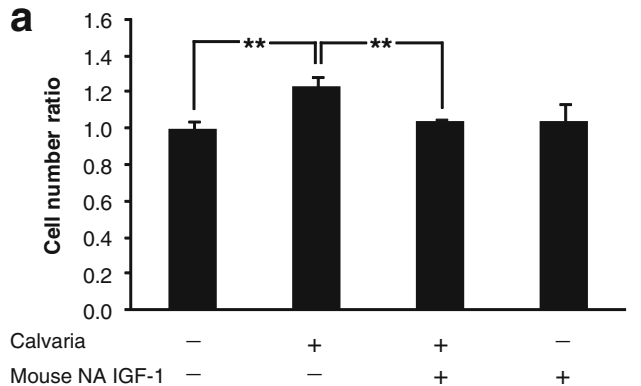

Fig. 1 Growth of PC-3 (a) and 22Rv1 (b) cells in co-culture with mice calvariae, with or without IGF-1 neutralization. A relative increase in cell numbers were observed when tumor cells were cultured $72 \mathrm{~h}$ in the presence of calvarial bones as compared to cells cultured alone. The calvarium-induced cell growth of PC-3 cells was completely abolished when a mouse-specific IGF-1 neutralizing antibody was added to the

was significantly decreasing with increasing drug concentrations $(0-12 \mu \mathrm{M}$, data not shown). Accordingly, when PC-3 and $22 \mathrm{Rv} 1$ cells were treated with simvastatin at increasing concentrations $(0-30 \mu \mathrm{M})$ for $72 \mathrm{~h}$ significantly decreased cell viability was observed (data not shown). To examine the combined effect of simvastatin and NVP-AEW541, the drugs were administrated together in the combination of $10 \mu \mathrm{M}$ simvastatin and $3 \mu \mathrm{M}$ NVP-AEW541 (Fig. 3). The viability of PC-3 and 22Rv1 cells incubated for $72 \mathrm{~h}$ with $10 \mu \mathrm{M}$ simvastatin was decreased to 34 and $69 \%$, respectively, compared to untreated cells $\left(P=5.7 \times 10^{-7}\right.$ and $\left.6.5 \times 10^{-6}\right)$, while the viabilities were reduced to 53 and $73 \%$ when the two tumor cell lines were treated with $3 \mu \mathrm{M}$ NVP-AEW541

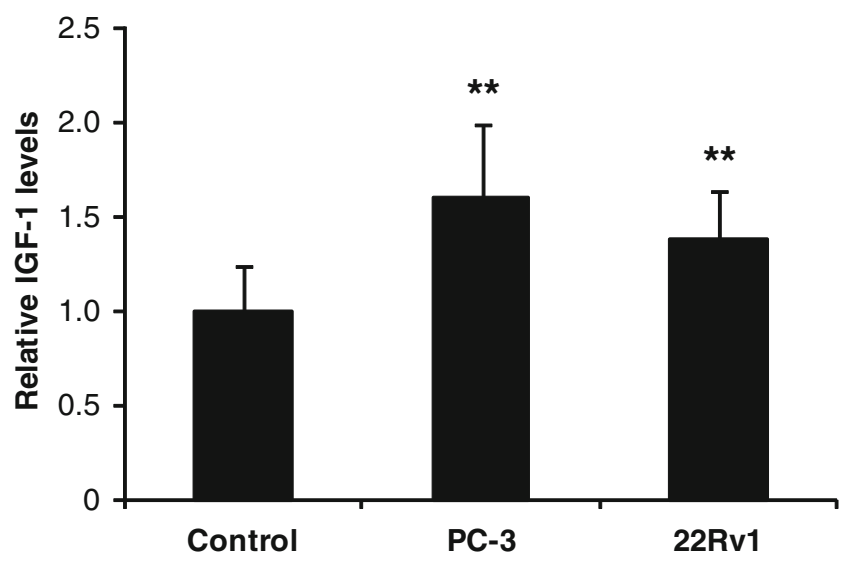

Fig. 2 Relative levels of IGF-1 released from mice calvariae after $72 \mathrm{~h}$ in co-culture with PC-3 or 22Rv1 cells. Levels of IGF-1 were determined in conditioned media from calvariae cultured with or without (control) tumor cells using an ELISA specific for detection of mouse IGF-1. Data is expressed in relation to control level (mean control level was $1,800 \mathrm{pg} / \mathrm{ml}$ ) and represents means \pm SD of two individual experiments with four to six replicates each. Statistically significant changes induced by the tumor cells were assessed using ANOVA and are shown by asterisks $(* * P<0.01)$

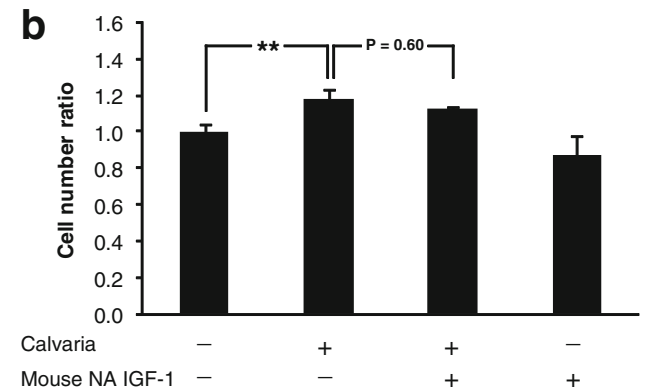

culture, while the $22 \mathrm{Rv} 1$ cell growth was non-significantly reduced. Data is expressed in relation to control level (number of untreated tumor cells set as 1) and represents means \pm SD of two individual experiments with four replicates each. Statistically significant changes induced by the calvariae and the inhibiting antibody were assessed using ANOVA and are shown by asterisks $(* * P<0.01)$

$\left(P=5.6 \times 10^{-6}\right.$ and $\left.1.6 \times 10^{-5}\right)$. The lowest cell viabilities; 19 and $29 \%$ for PC-3 and 22Rv1 cells, respectively, were obtained after the combined treatment of cells with $10 \mu \mathrm{M}$ simvastatin and $3 \mu \mathrm{M}$ NVP-AEW541 for $72 \mathrm{~h}\left(P=3.7 \times 10^{-5}\right.$ and $5.4 \times 10^{-7}$ in comparison to simvastatin treatment, $P=$ $8.0 \times 10^{-7}$ and $3.5 \times 10^{-7}$ in comparison to NVP-AEW541 treatment, Fig. 3).

Also when tumor cells were co-cultured with calvariae, the combination of $3 \mu \mathrm{M}$ NVP-AEW541 and $10 \mu \mathrm{M}$ simvastatin resulted in enhanced effects compared to effects of either drug when administrated alone. Total number of tumor cells was determined after $72 \mathrm{~h}$, and the combination of IGF-1R inhibition together with simvastatin treatment resulted in 33 and $30 \%$ viable $\mathrm{PC}-3$ and $22 \mathrm{Rv} 1$ cells, respectively $(P=0.042$ and 0.046 in comparison to simvastatin treatment, $P=3.1 \times 10^{-4}$ and $2.1 \times 10^{-8}$ in comparison to NVP-AEW541 treatment, Fig. 3). Accordingly, the proapoptotic effects on PC-3 and 22Rv1 cells in co-culture with calvariae were clearly higher when NVP-AEW541 and simvastatin were given in combination than when given as single agents (Fig. 4).

Simvastatin Treatment Reduces Expression of IGF-1R in PC-3 Cells and of AR-V7 in 22Rv1 Cells

Statins have previously been shown to cause down-regulation of IGF-1R expression in tumor cells [23, 24]. The tumor cell IGF-1R mRNA and proteins levels were therefore examined in co-cultures with calvariae in response to $10 \mu \mathrm{M}$ simvastatin and $3 \mu \mathrm{M}$ NVP-AEW541 treatment for $72 \mathrm{~h}$. Simvastatin alone or in combination with NVP-AEW541 reduced the IGF-1R mRNA levels about 0.7 -fold $\left(P=6.1 \times 10^{-4}\right.$ and $P=$ $2.6 \times 10^{-3}$ ) in PC-3 but not 22Rv1 cells (Fig. 5a). Accordingly, the IGF-1R protein levels in PC-3 cells were decreased by simvastatin and NVP-AEW541 treatment, while the levels in 22Rv1 cells were not clearly reduced (Fig. 5b-d). In contrast, 


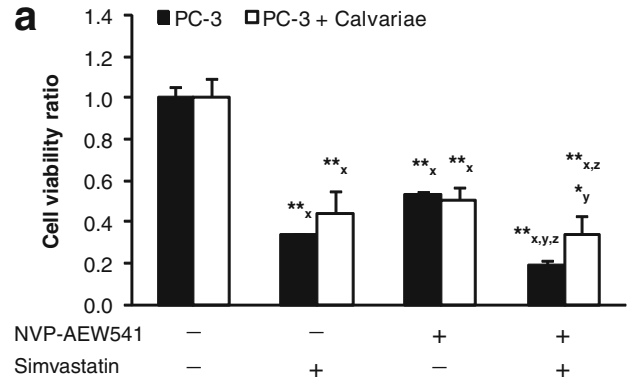

Fig. 3 Relative PC-3 (a) and 22Rv1 (b) cell viability when cells were cultured with or without mice calvariae and after treatment with combinations of $10 \mu \mathrm{M}$ simvastatin and $3 \mu \mathrm{M}$ NVP-AEW541. PC-3 and $22 \mathrm{Rv} 1$ cell viability was significantly reduced when cells were treated with simvastatin or NVP-AEW541 $(* * P<0.01)$. Tumor cell viability was further reduced when cells were treated with a combination of $10 \mu \mathrm{M}$ simvastatin and $3 \mu \mathrm{M}$ NVP-AEW541 compared to when the two treatments where administered individually ( $* * P<0.01$ and $* P<$

NVP-AEW541 stimulated a 1.6-fold $\left(P=1.6 \times 10^{-3}\right)$ increase of IGF-1R mRNA levels and a slight increase of IGF-1R protein levels in the 22Rv1 cells (Fig. 5a, c, d).

In 22Rv1 cells we hypothesized that simvastatin might affect expression of the androgen receptor (AR), as previously described for prostate cells [25]. In addition to the full length AR (ARfl), the 22Rv1 cells are known to express a series of alternatively spliced AR variants (AR-Vs) with molecular weights of approximately $75-80 \mathrm{kDa}$, including the AR-V7 (reviewed in [26]). We found that simvastatin treatment resulted in approximately $50 \%$ reductions of the AR-V7 mRNA and of the AR-V proteins, while the ARfl was not down-regulated (Fig. 6).

\section{Discussion}

In this study, using an in vitro model for PC and bone cell interactions, we show that bone-released IGF-1 creates a

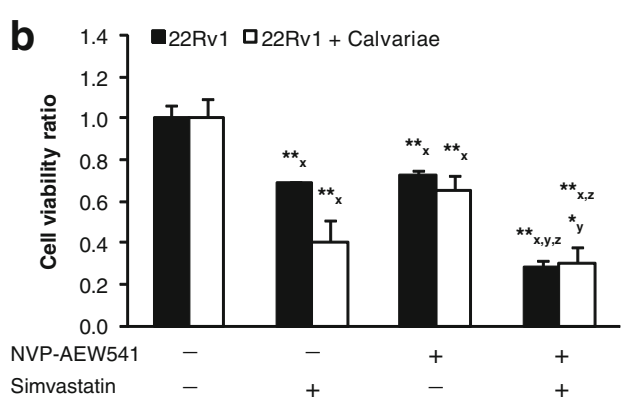

0.05). Data is expressed in relation to control level (number of viable untreated tumor cells set as 1) and represents means \pm SD of two individual experiments with four replicates each. Statistical significance was assessed using ANOVA and is marked with $\mathrm{x}$ when groups are compared to the control cells (no inhibitors), y when compared to simvastatin treatment only and $\mathrm{z}$ when compared with NVP-AEW541 treatment only

favorable micro-environment for PC cells. Through neutralization of bone-derived IGF-1 we observed that boneinduced stimulation of tumor cell growth was completely abolished in the lytic PC-3 cells while not significantly attenuated in the more sclerotic $22 \mathrm{Rv} 1$ cells. Both cell lines were however inhibited by the IGF-1R inhibitor NVPAEW541, indicating possible autocrine stimulation of the IGF-1R in the tumor cells and/or transactivation of the IGF$1 \mathrm{R}$ by other ligands. Importantly, the combined use of IGF$1 \mathrm{R}$ inhibition and simvastatin resulted in a more intense apoptotic stimuli in both tumor cell lines than either of the drugs administrated alone. We therefore speculate that not only lytic but also sclerotic PC bone metastases would benefit from IGF-1R inhibition given with the intention to reduce IGF-1R survival effects during administration of apoptosis-inducing therapies, e.g. castration therapy.

Castration therapy of PC acts by reducing the levels of circulating androgens in the patients, and this in turn results in reduced proliferation and increased apoptosis of PC cells [27].

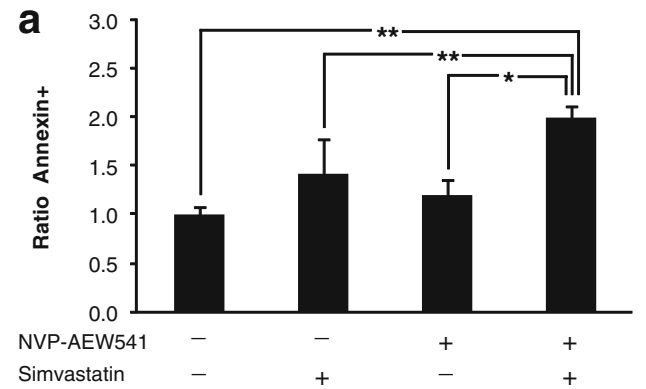

Fig. 4 Relative levels of apoptotic PC-3 (a) and 22Rv1 (b) tumor cells in co-culture with mice calvariae and after treatment with combinations of $10 \mu \mathrm{M}$ simvastatin and $3 \mu \mathrm{M}$ NVP-AEW541. Apoptosis in tumor cells after $72 \mathrm{~h}$ of co-culturing with calvariae and inhibitors was assessed using Annexin- $\mathrm{V}$ and propidium iodide (PI) staining, and

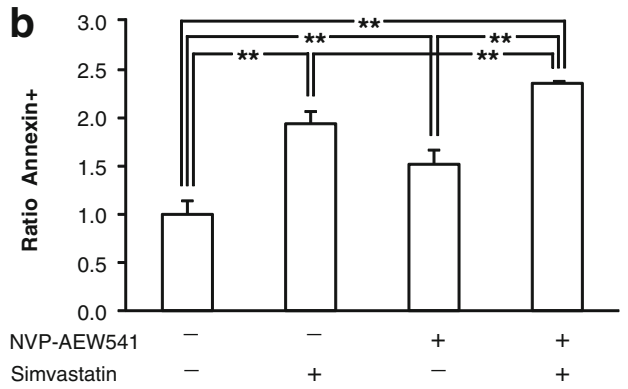

analyzed by flow cytometry. Data represents means \pm SD of four replicates and is expressed as Annexin V-positive/PI-negative staining in relation to control levels of untreated cells. Statistically significant changes induced by the inhibitors were assessed using ANOVA and are shown by asterisks $(* P<0.05, * * P<0.01)$ 


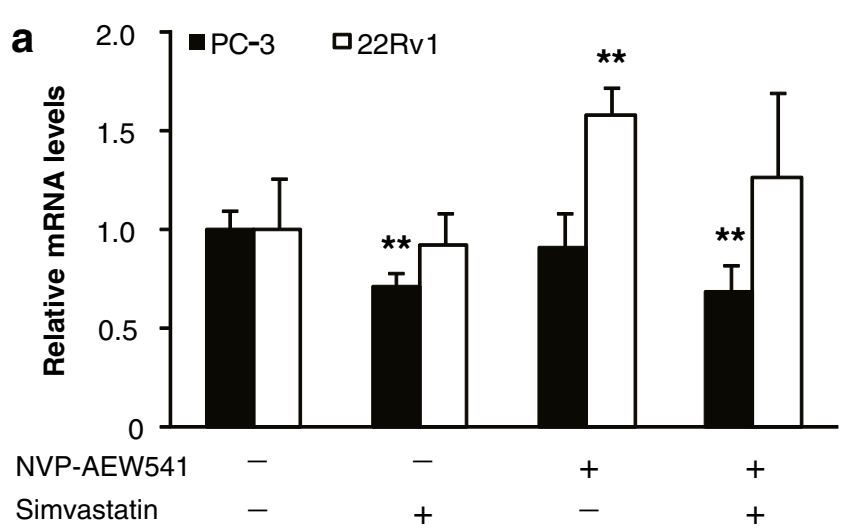

b

IGF-1R

$$
\text { PC-3 }
$$

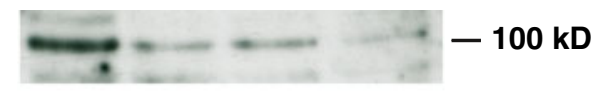

Actin

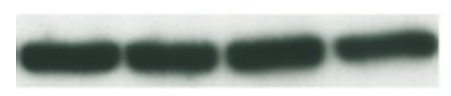

NVP-AEW541 $-\quad-\quad+\quad+$

Simvastatin $\quad-\quad+\quad-\quad+$

\section{Rv1}

IGF-1R

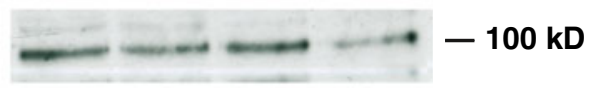

Actin

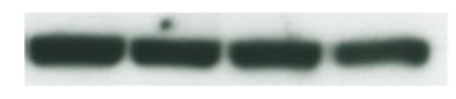

$\begin{array}{lllll}\text { NVP-AEW541 } & - & - & + & + \\ \text { Simvastatin } & - & + & - & +\end{array}$

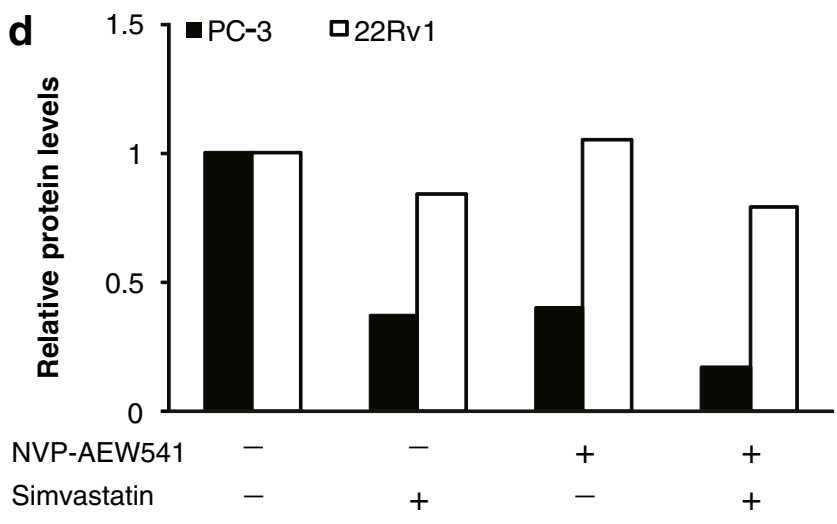

The precise mechanism behind apoptosis induction in the prostate and in prostate tumors after androgen ablation is not fully understood, but the general idea is that epithelial cells are both directly affected via reduced stimulation of their AR and indirectly affected through reduced stimulation of stromal cells. Normally, stromal cells produce various andromedins, such as IGF-1, which stimulate proliferation and inhibit
Fig. 5 Relative mRNA and protein levels of the IGF-1R in PC-3 and 22Rv1 tumor cells co-cultured with mice calvariae and treated with combinations of $10 \mu \mathrm{M}$ simvastatin and $3 \mu \mathrm{M}$ NVP-AEW541 for $72 \mathrm{~h}$. IGF-1R mRNA expression (a) was determined by real-time PCR and levels were normalized to RPL13 mRNA levels. Data represents means of five replicates $\pm \mathrm{SD}$ and is expressed in relation to control levels (levels in untreated cells set as 1). Statistically significant changes induced by the tumor cells were assessed using ANOVA and are shown by asterisks $(* * P<0.01)$. Protein levels of IGF-1R was determined by Western blot analysis of pooled replicative samples $(n=5)$ and normalized to corresponding actin levels $(\mathbf{b}, \mathbf{c}$ and $\mathbf{d})$

apoptosis of epithelial and vascular cells in the prostate [28, 29]. It has been shown in mouse and rat prostate that paracrine IGF-1 signals from the stroma rapidly drops after castration $[28,30]$ and in patients reduction of IGF-1 levels in the tumor stroma after castration correlates with increased tumor cell apoptosis [31]. Bone metastases are believed to show an attenuated response to castration therapy compared to primary prostate tumors. One of the reasons for this could be that the IGF-1 levels in the bone microenvironment, in contrast to the IGF-1 levels in prostate stroma, remain high also after androgendeprivation and continue to stimulate the metastatic tumor cells. Therefore, inhibition of IGF-1 signaling meanwhile giving castration therapy may be a way to instantly reduce the survival effects mediated by bone-derived IGF-1 and thereby enhance effects of castration. Furthermore, continuous IGF-1R inhibition administered after castration therapy may be a way to postpone AR reactivation and development of castration-resistant PC (CRPC), as indicated by Plymate and co-workers [32]. The combination of IGF-1R inhibition with inducers of apoptosis, such as cytostatic drugs or statins, may also provide great potential as novel treatment strategies for PC patients. Thus, high levels of IGF-1 present in the bone microenvironment may provide constant anti-apoptotic, pro-survival signals to the tumor cells, and probably lessen the effects of proapoptotic therapeutic drugs. By IGF-1R inhibition, we hypothesize that pro-survival signals can be diminished and apoptosis signals enhanced in metastatic tumor cells. In line with this idea, preclinical studies of multiple myeloma, lung cancer, and PC have shown that inhibition of IGF-1R signaling enhances the effects of radiotherapy and various chemotherapies [33-36].

Statins act in the mevalonate pathway and has been found to affect tumor cells both in cholesterol-dependent and cholesterol-independent ways. Cholesterol is an important element of specific plasma membrane structures known as lipid rafts [37]. Inhibition of cholesterol levels by statins may lead to raft disruption, and deregulated cell signaling through the rafts $[18,38]$. The PI3K-Akt pathway is highly active in many cancer cells and is a key regulator of cell survival [39]. Simvastatin has been shown to inhibit Akt signaling and to induce apoptosis in tumor cells, including PC-3 cells [18]. The PI3K-Akt pathway is furthermore activated down-stream of the IGF-1R and lipid rafts are essential for IGF-1R signaling [40], indicating that IGF-1R inhibitors 

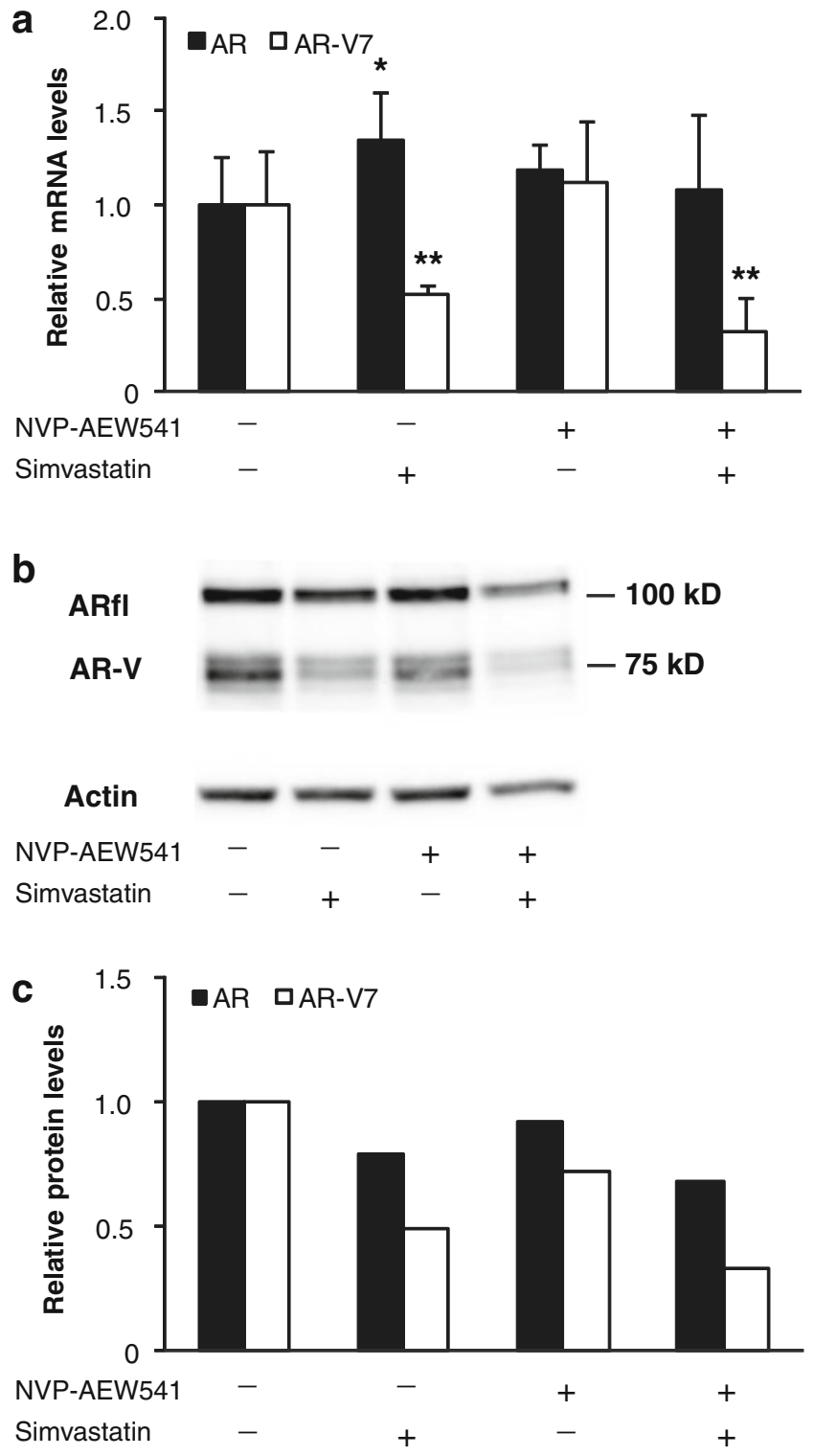

Fig. 6 Relative mRNA and protein levels of the AR and of truncated AR variants in $22 \mathrm{Rv} 1$ cells co-cultured with mice calvariae and treated with combinations of $10 \mu \mathrm{M}$ simvastatin and $3 \mu \mathrm{M}$ NVP-AEW541 for $72 \mathrm{~h}$. The AR and AR-V7 mRNA levels (a) were determined by realtime RT-PCR and normalized to RPL13 mRNA levels. Data represents means \pm SD of five replicates and is expressed in relation to control levels (levels in untreated cells set as 1). Statistically significant changes induced by the tumor cells were assessed using ANOVA and are shown by asterisks $(* P<0.05, * * P<0.01)$. Protein levels of full length $\mathrm{AR}(\mathrm{ARfl})$ and truncated $\mathrm{AR}$ variants $(\mathrm{AR}-\mathrm{V})$ were determined by Western blot analysis of pooled replicative samples $(n=5)$ and normalized to corresponding actin levels (b and $\mathbf{c}$ )

and statins at least partly act by affecting the same intracellular pathways. In this study, we examined the expression levels of the IGF-1R and found that simvastatin was able to reduce the IGF-1R expression in PC-3 cells, which is similar to what others have previously shown both in PC and melanoma cell lines [23, 24]. In 22Rv1 cells, however, the IGF-1R expression was not reduced by simvastatin treatment. Still, the inhibitory effects of simvastatin in the $22 \mathrm{Rv} 1$ cells were prominent, and we examined if simvastatin had any effect on the AR expression level as have been recently indicated by others [25]. Most importantly, simvastatin was able to reduce the mRNA and protein expression level of the ARV7 splice variant that is supposed to possess constitutive activity, while the levels of the full length AR were not obviously reduced. Expression of ligand-independent AR variants is believed to contribute to the development and growth of CRPC [26, 41-43], and it is thus possible that statin treatment could be of benefit for patients expressing AR variants, as a complement to anti-androgen therapies targeting the full length receptor.

In conclusion, we show that the bone is a favorable growth environment for PC cells that partly could be attributed to bone-derived IGF-1. Tumor cells enhance the IGF-1 release from bone and this probably originates both from increased IGF-1 synthesis in bone cells and from increased bone resorption, as previously indicated [4]. Administration of the IGF1R inhibitor NVP-AEW541 to PC cells in co-culture with bone intensifies growth inhibiting effects of simvastatin, and indicates that IGF-1 inhibition may be a way to strengthen effects of pro-apoptotic therapies of PC bone metastases. This possibility needs to be further tested in pre-clinical models.

\section{Materials and Methods}

\section{Cell Lines and Cell Culture}

The PC-3 and 22Rv1 tumor cell lines were purchased from American Type Culture Collection (ATCC) and maintained in RPMI 1640 (Invitrogen, Stockholm, Sweden) supplemented with $10 \%$ fetal bovine serum (FBS; Invitrogen) and $50 \mu \mathrm{g} / \mathrm{ml}$ gentamicin (Invitrogen), at $37^{\circ} \mathrm{C}$ in a humified atmosphere with $5 \% \mathrm{CO}_{2}$. In all experiments this culture medium was used to seed the cells. After $24 \mathrm{~h}$ the culture medium was replaced with bone culture medium; $\alpha$ MEM (Invitrogen) supplemented with $0.1 \%$ albumin, and cells were incubated for an additional $24 \mathrm{~h}$. After this the medium was replaced with new bone culture medium with supplements as described in each experiment. Simvastatin (SIGMA-ALDRICH) and NVP-AEW541 (Novartis Pharmaceuticals) were handled and simvastatin activated according to manufacturer's description. Cells were treated with simvastatin and NVP-AEW541 according to the dosages and times indicated in the experiments.

\section{Co-Culture Model}

The co-culture model was previously described in [4]. Tumor cells were seeded in culture medium (described 
above) at concentrations of $10^{5}$ cells/well (PC-3) and $1.5 \times$ $10^{5}$ cells/well $(22 \mathrm{Rv} 1)$ in 6 -well plates. After $24 \mathrm{~h}$ culture medium was replaced with bone culture medium; $\alpha$ MEM (Invitrogen) supplemented with $0.1 \%$ albumin, and cells were incubated for additional $24 \mathrm{~h}$. Thereafter, cells received new bone culture medium ( $4 \mathrm{ml} / \mathrm{well})$ and after 3-4 h calvarial bones were placed on metal grids in the wells, separating the bones from the tumor cells but still allowing signaling through the medium between the two compartments. The calvarial bones were dissected from 6 to 7-dayold-mice, cut into halves, pre-incubated with indomethacin $\left(10^{-6}\right)$ in bone culturing medium for $24 \mathrm{~h}$ and subsequently washed according to Lerner et al. [44].

Calvarial bones for co-culture experiments were obtained from CsA mice from our own inbred colony. All animal experiments were approved by the local ethical committee for animal research.

\section{Neutralization of IGF-1}

Neutralization of calvariae-released IGF-1 in co-cultures was performed using an anti-mouse IGF-1 antibody (R\&D Systems, Abingdon, UK). The neutralizing antibody was added to the cultures when calvariae were placed in the wells, at a concentration of $0.3 \mu \mathrm{g} / \mathrm{ml}$. After $72 \mathrm{~h}$ of co-culture cell growth was determined.

\section{Evaluation of Cell Growth and Cell Viability}

At the end of the co-culture experiments cells were harvested with trypsin, mixed with $0.4 \%$ trypan blue (at a 1:1 dilution) and number of viable, non-stained cells was determined using a Countess ${ }^{\mathrm{TM}}$ automated cell counter (Invitrogen).

Tumor cell viability was determined by measuring the conversion of 3 (4,5-dimethythiazozyl-2)-2,5 diphenyl tetrazolium bromide (MTT) to purple formazan product using the Cell Proliferation Kit I (Roche Diagnostics, Bromma, Sweden) according to the manufacturer's instructions.

\section{Phospho-RTK Array}

A human Phospho-RTK Array (R\&D Systems) detecting phosphorylation status of 42 different RTKs was used to screen for bone-induced RTK activation in tumor cells. Tumor cells were seeded as described above (see 'Co-culture model') and grown in bone culturing medium for $72 \mathrm{~h}$. Medium was removed and tumor cells were stimulated with calvariaeconditioned medium (from calvariae cultured in bone culture medium for $72 \mathrm{~h}$ ) for $10 \mathrm{~min}$ and then immediately placed on ice. Cells were washed with cold PBS and solubilized in lysis buffer containing $1 \%$ Igepal CA-630 (Sigma-Aldrich, ST. Louis, MO), $20 \mathrm{mM}$ Tris- $\mathrm{HCl}$ (pH 8.0), $137 \mathrm{mM} \mathrm{NaCl}$, $10 \%$ glycerol, 2 mM EDTA, Complete Protease Inhibitor (Roche Diagnostics) and $10 \mu \mathrm{L} / \mathrm{mL}$ Halt ${ }^{\mathrm{TM}}$ Phosphatase Inhibitor Cocktail (Thermo Scientific, Rockford, IL). Samples were incubated on ice for $30 \mathrm{~min}$ and centrifuged $(14,000 \mathrm{x} \mathrm{g}$ for $5 \mathrm{~min})$ to isolate the supernatants. Protein concentration was determined using BCA Protein Assay Kit (Thermo Scientific) and the Phospho-RTK array was performed according to the manufacturer's instructions using $100 \mu \mathrm{g}$ of PC-3 samples and $150 \mu \mathrm{g}$ of 22Rv1 samples. RTK phosphorylations were detected using the ELC Plus Western Blotting Detection System (GE Healthcare, Buckinghamshire, UK). Average pixel density was determined using the Quantity-one software (Bio-Rad Laboratories, Hercules, CA) and average pixel density of duplicate spots was normalized to positive control spots.

\section{IGF-1 ELISA}

Tumor cells and calvarial bones were cultured as described above (see 'Co-culture model'). After $72 \mathrm{~h}$ culture medium was harvested, particulates removed by centrifugation, and samples stored at $-20{ }^{\circ} \mathrm{C}$. Tumor cell and calvarial secretion of IGF-1 was measured by the human (DG100) and mouse (MG100) specific IGF-1 Quantikine ELISAs, respectively, (R\&D Systems) according to protocols.

\section{Flow Cytometry}

After $72 \mathrm{~h}$ of co-culture, tumor cells were harvested and washed once in PBS. Approximately 200,000 cells were placed in round-bottom 96-well plates and apoptosis was assessed using the FITC Annexin-V Apoptosis Detection Kit (BD Pharmingen) according to manufacturer's instructions. Staining was determined by flow cytometry (FACSCalibur,

Table 1 Primers used for quantitative real-time PCR

\begin{tabular}{lll}
\hline Gene & Forward primer & Reverse primer \\
\hline RPL13 & 5'-CCG CTC TGG ACC GTC TCA A-3' & 5'-CCT GGT ACT TCC AGC CAA CCT-3' \\
IGF-1 & 5'-CAG CAG TCT TCC AAC CCA AT-3' & 5'- TGG TGT GCA TCT TCA CCT TC-3' \\
IGF-1R & 5'-AGG AAC AAC GGG GAG AGA GC-3' & 5'-ACC GGT GCC AGG TTA TGA TG-3' \\
AR & 5'-CCA TCT TGT CGT CTT CGG AAA TGT TAT GAA GC-3' & 5'-AGC TTC TGG GTT GTC TCC TCA GTG G-3' \\
AR-V7 & 5'-CCA TCT TGT CGT CTT CGG AAA TGT TAT GAA GC-3' & 5'-TTT GAA TGA GGC AAG TCA GCC TTT CT-3' \\
\hline
\end{tabular}


BD Biosciences FACS) and analyzed using CellQuest software (BD).

\section{RNA Extraction and cDNA Synthesis}

Total RNA was extracted from the tumor cells using the RNAqueous kit (Ambion, Huntingdon, UK) according to the manufacturer's instructions. Total RNA was DNasetreated with TURBO DNase (Ambion) and RNA concentrations were determined using a Nanodrop ND-1000 (Nanodrop Technologies, Wilmington, DE). Using the High Capacity cDNA Reverse Transcription kit (Applied Biosystems), 500 ng of RNA was reverse transcribed. Resulting cDNA samples were diluted 10 times and stored at $-20^{\circ} \mathrm{C}$.

Quantitative Real-Time Polymerase Chain Reaction (PCR)

Quantitative real-time PCR of RPL13, IGF-1, IGF-1R, AR and AR-V7 (Table 1) mRNA levels was performed using the ABI PRISM 7900 HT Sequence Detection System (Applied Biosystems, Foster City, CA) and the Power SYBR Green PCR Master Mix (Applied Biosystems) according to protocol. $\mathrm{Ct}$ values were analyzed with the standard curve method (User Bulletin \#2, Applied Biosystems) and IGF-1, IGF-1R, AR and AR-V7 mRNA levels were normalized to house-keeping gene RPL13 mRNA levels.

\section{Western Blot Analysis}

Proteins were extracted using $1 \%$ Igepal CA-630 (SigmaAldrich), $20 \mathrm{mM}$ Tris- $\mathrm{HCl}$ (pH 8.0), $137 \mathrm{mM} \mathrm{NaCl}, 10 \%$ glycerol, $2 \mathrm{mM}$ EDTA and Complete Protease Inhibitor (Roche Diagnostics) and protein concentration was determined by the BCA Protein assay (Pierce Chemical Co., IL, USA). Samples ( $4-20 \mu \mathrm{g}$ protein) were separated by $7.5 \%$ SDS-PAGE under reducing conditions and subsequently transferred to PVDF membranes. Membranes were blocked in $5 \%$ milk before incubated with the anti-AR antibody over night in $4{ }^{\circ} \mathrm{C}(\mathrm{N}-20$, Santa Cruz Biotechnology, Santa Cruz, CA, diluted 1:500 in $1 \%$ milk/PBST,), in order to detect the full length AR and AR variants with an intact Nterminal domain. Secondary anti-rabbit IgG antibody (Dako, Glostrup, Denmark, diluted 1:20 000 in $2.5 \%$ milk) was applied after washing in PBST and incubated for $1 \mathrm{~h}$ in RT. Protein expression was visualized after extensive washing using the ECL Advanced detection kit (GE Healthcare, Buckinghamshire, UK) and quantified with a ChemiDoc scanner and the Quantity One 4 software (Bio-Rad Laboratories). IGF-1R was detected using the AF-305-NA antibody (diluted 1:500, R\&D Systems, Abington, UK), secondary anti-goat IgG antibody (diluted 1:20 000, Dako), and the ECL Plus detection kit (GE Healthcare). Membranes were stripped and re-analyzed as above with primary antibody against actin (diluted 1:8000, SIGMA, Saint Louis. Missouri). The relative AR levels were adjusted for the corresponding actin levels.

\section{Statistics}

In each experiment, data was expressed in relation to control values (with control mean value set to 1 ) and showed as mean \pm SD. Results were analysed using ANOVA and Student's $t$-test. A $P$-value below 0.05 was considered statistically significant.

Acknowledgments This work was supported by grants from the Swedish Cancer Society, the Cancer Research Foundation in Northern Sweden, Lion's Cancer Research Foundation, regional ALF support from Västerbotten County Council, and Umeå University. NVPAEW541 was kindly provided by Novartis Pharmaceuticals.

Open Access This article is distributed under the terms of the Creative Commons Attribution License which permits any use, distribution, and reproduction in any medium, provided the original author(s) and the source are credited.

\section{References}

1. Coleman RE (2001) Metastatic bone disease: clinical features, pathophysiology and treatment strategies. Cancer Treat Rev 27 (3):165-176. doi:10.1053/ctrv.2000.0210

2. Linkhart TA, Mohan S, Baylink DJ (1996) Growth factors for bone growth and repair: IGF, TGF beta and BMP. Bone 19(1 Suppl):1S-12S

3. Garnero P, Buchs N, Zekri J, Rizzoli R, Coleman RE, Delmas PD (2000) Markers of bone turnover for the management of patients with bone metastases from prostate cancer. Br J Cancer 82(4):858864. doi:10.1054/bjoc.1999.1012

4. Nordstrand A, Nilsson J, Tieva A, Wikstrom P, Lerner UH, Widmark A (2009) Establishment and validation of an in vitro co-culture model to study the interactions between bone and prostate cancer cells. Clin Exp Metastasis 26(8):945-953. doi:10.1007/ s10585-009-9285-4

5. Roddam AW, Allen NE, Appleby P, Key TJ, Ferrucci L, Carter HB, Metter EJ, Chen C, Weiss NS, Fitzpatrick A, Hsing AW, Lacey JV Jr, Helzlsouer K, Rinaldi S, Riboli E, Kaaks R, Janssen JA, Wildhagen MF, Schroder FH, Platz EA, Pollak M, Giovannucci E, Schaefer C, Quesenberry CP Jr, Vogelman JH, Severi G, English DR, Giles GG, Stattin P, Hallmans G, Johansson M, Chan JM, Gann P, Oliver SE, Holly JM, Donovan J, Meyer F, Bairati I, Galan P (2008) Insulin-like growth factors, their binding proteins, and prostate cancer risk: analysis of individual patient data from 12 prospective studies. Ann Intern Med 149(7):461-471

6. Rowlands MA, Gunnell D, Harris R, Vatten LJ, Holly JM, Martin RM (2009) Circulating insulin-like growth factor peptides and prostate cancer risk: a systematic review and meta-analysis. Int $\mathrm{J}$ Cancer 124(10):2416-2429. doi:10.1002/ijc.24202

7. Hewish M, Chau I, Cunningham D (2009) Insulin-like growth factor 1 receptor targeted therapeutics: novel compounds and novel treatment strategies for cancer medicine. Recent Pat Anticancer Drug Discov 4(1):54-72

8. Turney BW, Turner GD, Brewster SF, Macaulay VM (2011) Serial analysis of resected prostate cancer suggests up-regulation of type 1 IGF receptor with disease progression. BJU Int 107(9):14881499. doi:10.1111/j.1464-410X.2010.09556.X 
9. de Bono JS, Attard G, Adjei A, Pollak MN, Fong PC, Haluska P, Roberts L, Melvin C, Repollet M, Chianese D, Connely M, Terstappen LW, Gualberto A (2007) Potential applications for circulating tumor cells expressing the insulin-like growth factor-I receptor. Clin Cancer Res 13(12):3611-3616. doi:10.1158/10780432.CCR-07-0268

10. Ryan CJ, Haqq CM, Simko J, Nonaka DF, Chan JM, Weinberg V, Small EJ, Goldfine ID (2007) Expression of insulin-like growth factor-1 receptor in local and metastatic prostate cancer. Urol Oncol 25(2):134-140. doi:10.1016/j.urolonc.2006.07.019

11. Hellawell GO, Turner GD, Davies DR, Poulsom R, Brewster SF, Macaulay VM (2002) Expression of the type 1 insulin-like growth factor receptor is up-regulated in primary prostate cancer and commonly persists in metastatic disease. Cancer Res 62(10):2942-2950

12. Parrizas M, Saltiel AR, LeRoith D (1997) Insulin-like growth factor 1 inhibits apoptosis using the phosphatidylinositol $3^{\prime}$-kinase and mitogen-activated protein kinase pathways. J Biol Chem 272 (1):154-161

13. Kulik G, Weber MJ (1998) Akt-dependent and -independent survival signaling pathways utilized by insulin-like growth factor I. Mol Cell Biol 18(11):6711-6718

14. Grothey A, Voigt W, Schober C, Muller T, Dempke W, Schmoll HJ (1999) The role of insulin-like growth factor I and its receptor in cell growth, transformation, apoptosis, and chemoresistance in solid tumors. J Cancer Res Clin Oncol 125(3-4):166-173

15. Buck E, Mulvihill M (2011) Small molecule inhibitors of the IGF$1 \mathrm{R} / \mathrm{IR}$ axis for the treatment of cancer. Expert Opin Investig Drugs 20(5):605-621. doi:10.1517/13543784.2011.558501

16. Heidegger I, Pircher A, Klocker H, Massoner P (2011) Targeting the insulin-like growth factor network in cancer therapy. Cancer Biol Ther 11(8):701-707

17. Thysell E, Surowiec I, Hornberg E, Crnalic S, Widmark A, Johansson AI, Stattin P, Bergh A, Moritz T, Antti H, Wikstrom P (2010) Metabolomic characterization of human prostate cancer bone metastases reveals increased levels of cholesterol. PLoS One 5(12):e14175. doi:10.1371/journal.pone.0014175

18. Zhuang L, Kim J, Adam RM, Solomon KR, Freeman MR (2005) Cholesterol targeting alters lipid raft composition and cell survival in prostate cancer cells and xenografts. J Clin Invest 115(4):959968. doi:10.1172/JCI19935

19. Hoque A, Chen H, Xu XC (2008) Statin induces apoptosis and cell growth arrest in prostate cancer cells. Cancer Epidemiol Biomark Prev 17(1):88-94. doi:10.1158/1055-9965.EPI-07-0531

20. Papadopoulos G, Delakas D, Nakopoulou L, Kassimatis T (2011) Statins and prostate cancer: molecular and clinical aspects. Eur J Cancer 47(6):819-830. doi:10.1016/j.ejca.2011.01.005

21. Garcia-Echeverria C, Pearson MA, Marti A, Meyer T, Mestan J, Zimmermann J, Gao J, Brueggen J, Capraro HG, Cozens R, Evans DB, Fabbro D, Furet P, Porta DG, Liebetanz J, Martiny-Baron G, Ruetz S, Hofmann F (2004) In vivo antitumor activity of NVPAEW541-A novel, potent, and selective inhibitor of the IGF-IR kinase. Cancer Cell 5(3):231-239

22. Scotlandi K, Manara MC, Nicoletti G, Lollini PL, Lukas S, Benini S, Croci S, Perdichizzi S, Zambelli D, Serra M, Garcia-Echeverria C, Hofmann F, Picci P (2005) Antitumor activity of the insulin-like growth factor-I receptor kinase inhibitor NVP-AEW541 in musculoskeletal tumors. Cancer Res 65(9):3868-3876. doi:10.1158/ 0008-5472.CAN-04-3192

23. Carlberg M, Dricu A, Blegen H, Wang M, Hjertman M, Zickert P, Hoog A, Larsson O (1996) Mevalonic acid is limiting for N-linked glycosylation and translocation of the insulin-like growth factor-1 receptor to the cell surface. Evidence for a new link between 3hydroxy-3-methylglutaryl-coenzyme a reductase and cell growth. J Biol Chem 271(29):17453-17462

24. Sekine Y, Furuya Y, Nishii M, Koike H, Matsui H, Suzuki K (2008) Simvastatin inhibits the proliferation of human prostate cancer PC-3 cells via down-regulation of the insulin-like growth factor 1 receptor. Biochem Biophys Res Commun 372(2):356361. doi:10.1016/j.bbrc.2008.05.043

25. Yokomizo A, Shiota M, Kashiwagi E, Kuroiwa K, Tatsugami K, Inokuchi J, Takeuchi A, Naito S (2011) Statins reduce the androgen sensitivity and cell proliferation by decreasing the androgen receptor protein in prostate cancer cells. Prostate 71(3):298-304. doi: $10.1002 /$ pros. 21243

26. Dehm SM, Tindall DJ (2011) Alternatively spliced androgen receptor variants. Endocr Relat Cancer 18(5):R183-R196. doi:10.1530/ERC-11-0141

27. Ohlson N, Wikstrom P, Stattin P, Bergh A (2005) Cell proliferation and apoptosis in prostate tumors and adjacent non-malignant prostate tissue in patients at different time-points after castration treatment. Prostate 62(4):307-315. doi:10.1002/pros.20139

28. Ohlson N, Bergh A, Persson ML, Wikstrom P (2006) Castration rapidly decreases local insulin-like growth factor-1 levels and inhibits its effects in the ventral prostate in mice. Prostate 66 (16):1687-1697. doi:10.1002/pros.20368

29. Cohen P, Peehl DM, Lamson G, Rosenfeld RG (1991) Insulin-like growth factors (IGFs), IGF receptors, and IGF-binding proteins in primary cultures of prostate epithelial cells. J Clin Endocrinol Metab 73(2):401-407

30. Nickerson T, Pollak M, Huynh H (1998) Castration-induced apoptosis in the rat ventral prostate is associated with increased expression of genes encoding insulin-like growth factor binding proteins 2,3,4 and 5. Endocrinology 139(2):807-810

31. Ohlson N, Bergh A, Stattin P, Wikstrom P (2007) Castrationinduced epithelial cell death in human prostate tissue is related to locally reduced IGF-1 levels. Prostate 67(1):32-40. doi:10.1002/ pros. 20480

32. Plymate SR, Haugk K, Coleman I, Woodke L, Vessella R, Nelson P, Montgomery RB, Ludwig DL, Wu JD (2007) An antibody targeting the type I insulin-like growth factor receptor enhances the castrationinduced response in androgen-dependent prostate cancer. Clin Cancer Res 13(21):6429-6439. doi:10.1158/1078-0432.CCR-07-0648

33. Allen GW, Saba C, Armstrong EA, Huang SM, Benavente S, Ludwig DL, Hicklin DJ, Harari PM (2007) Insulin-like growth factor-I receptor signaling blockade combined with radiation. Cancer Res 67 (3):1155-1162. doi:10.1158/0008-5472.CAN-06-2000

34. Descamps G, Gomez-Bougie P, Venot C, Moreau P, Bataille R, Amiot M (2009) A humanised anti-IGF-1R monoclonal antibody (AVE1642) enhances Bortezomib-induced apoptosis in myeloma cells lacking CD45. Br J Cancer 100(2):366-369. doi:10.1038/ sj.bjc. 6604839

35. Baumann P, Hagemeier H, Mandl-Weber S, Franke D, Schmidmaier R (2009) Myeloma cell growth inhibition is augmented by synchronous inhibition of the insulin-like growth factor-1 receptor by NVP-AEW541 and inhibition of mammalian target of rapamycin by Rad001. Anticancer Drugs 20(4):259-266. doi:10.1097/CAD.0b013e328328d18b

36. Wu JD, Haugk K, Coleman I, Woodke L, Vessella R, Nelson P, Montgomery RB, Ludwig DL, Plymate SR (2006) Combined in vivo effect of A12, a type 1 insulin-like growth factor receptor antibody, and docetaxel against prostate cancer tumors. Clin Cancer Res 12(20 Pt 1):6153-6160. doi:10.1158/1078-0432.CCR-06-0443

37. Lingwood D, Simons K (2010) Lipid rafts as a membraneorganizing principle. Science 327(5961):46-50. doi:10.1126/ science. 1174621

38. Li YC, Park MJ, Ye SK, Kim CW, Kim YN (2006) Elevated levels of cholesterol-rich lipid rafts in cancer cells are correlated with apoptosis sensitivity induced by cholesterol-depleting agents. Am J Pathol 168(4):1107-1118, quiz 1404-1105

39. Altomare DA, Testa JR (2005) Perturbations of the AKT signaling pathway in human cancer. Oncogene 24(50):7455-7464. doi:10.1038/sj.onc. 1209085 
40. Hong S, Huo H, Xu J, Liao K (2004) Insulin-like growth factor-1 receptor signaling in 3T3-L1 adipocyte differentiation requires lipid rafts but not caveolae. Cell Death Differ 11(7):714-723. doi:10.1038/sj.cdd.4401405

41. Hu R, Dunn TA, Wei S, Isharwal S, Veltri RW, Humphreys E, Han M, Partin AW, Vessella RL, Isaacs WB, Bova GS, Luo J (2009) Ligand-independent androgen receptor variants derived from splicing of cryptic exons signify hormone-refractory prostate cancer. Cancer Res 69(1):16-22. doi:10.1158/00085472.CAN-08-2764

42. Guo Z, Yang X, Sun F, Jiang R, Linn DE, Chen H, Kong X, Melamed J, Tepper CG, Kung HJ, Brodie AM, Edwards J, Qiu Y (2009) A novel androgen receptor splice variant is up-regulated during prostate cancer progression and promotes androgen depletion-resistant growth. Cancer Res 69(6):2305-2313. doi:10.1158/00085472.CAN-08-3795

43. Hornberg E, Ylitalo EB, Crnalic S, Antti H, Stattin P, Widmark A, Bergh A, Wikstrom P (2011) Expression of androgen receptor splice variants in prostate cancer bone metastases is associated with castration-resistance and short survival. PLoS One 6(4): e19059. doi:10.1371/journal.pone.0019059

44. Lerner UH (1987) Modifications of the mouse calvarial technique improve the responsiveness to stimulators of bone resorption. J Bone Miner Res 2(5):375-383. doi:10.1002/jbmr.5650020504 